\title{
IMPACTS OF PATTERNS OF ECONOMIC AGENTS ACTIVITIES IN THE SEMERU VOLCANO CONSERVATION AREA
}

\author{
Nuansa Bayu Segara', Iin Wariin Basyari² \\ ${ }^{1}$ Fakultas Ilmu Sosial dan Hukum, Universitas Negeri Surabaya \\ Jl. Ketintang No.i8, Ketintang, Kec. Gayungan, Kota Surabaya, Jawa Timur, 60231, Indonesia \\ ${ }^{2}$ Fakultas Keguruan dan Ilmu Pendidikan, Universitas Swadaya Gunung Jati \\ Jl. Perjuangan No.01 Cirebon, Jawa Barat, 45132, Indonesia \\ e-mail: nuansasegara@unesa.ac.id
}

Received: 17 January 2020, Repaired: 09 July 2020, Approved: 25 November 2020

\begin{abstract}
Semeru volcano is the most popular mount hiking tourism in Indonesia. The economic community and conservation area are affected by these activities. This research focuses on the development activities of economic agents pattern and explains the impact of high tourism in the Semeru Volcano conservation area. It was a qualitative study, and the participative observatory was a procedure for collecting the data. The location was not limited in the Semeru Volcano, but also social media, Instagram. The result of the research reveals that there are two kinds of economic agents, namely internal and external. They have positive connectedness to support hiking activities. Although there should be potential for competition between open trip services and local guides, this does not happens, due to the wisdom of internal economic actors, especially local guides. Moreover, the consequences of high tourism activities in the Semeru Volcano conservation area are waste and erosion. The article is concluded by proposing several directions for economic agents to be involved more in conservation activities and positive business in the Semeru Volcano.
\end{abstract}

Keywords: Semeru Volcano, economic agent, conservation area, mount tourism

\begin{abstract}
Abstrak
Gunungapi Semeru merupakan wisata pendakian gunung yang paling populer di Indonesia. Aktivitas ini tentu berdampak terhadap perekonomian penduduk sekitar dan lingkungan di kawasan konservasi. Artikel ini mengkaji pola aktivitas dan pelaku ekonomi yang terlibat dalam perkembangan wisata, dan mengungkap dampak tingginya aktivitas ini terhadap Kawasan Konservasi Gunungapi Semeru itu sendiri. Penelitian ini menggunakan pendekatan kualitatif yang bersifat ekploratif. Pengumpulan data dilakukan secara observasi partisipatif dan tidak terbatas di kawasan pendakian, namun juga melakukan observasi di media sosial instagram. Hasil penelitian menujukan pelaku ekonomi terdiri dari internal dan eksternal kawasan, yang memiliki keterkaitan positif antar pelaku ekonomi dari luar dan dalam Kawasan Pendakian. Meskipun semestinya ada potensi persaingan antara jasa open trip dengan pemandu lokal, akan tetapi hal itu tidak terjadi, karena kearifan pelaku ekonomi internal, khususnya para pemandu lokal. Dampak tingginya aktivitas wisata pendakian ini mengakibatkan dua permasalahan yang cukup serius, yaitu sampah dan erosi. Artikel ini diakhiri dengan memberikan beberapa usulan terkait dengan peningkatan keterlibatan pelaku ekonomi dalam melakukan usaha dan aktivitas konservasi di Kawasan Gunung Semeru.
\end{abstract}

Kata kunci: Gunungapi Semeru, pelaku ekonomi, kawasan konservasi, wisata gunung 


\section{INTRODUCTION}

Volcanoes are synonymous with the causes of disaster and damage. There are many disadvantages and negative and positive impacts felt by humans from the existence of volcanoes. Indonesia having more than 100 active volcanoes (SI-USGS, 2009) continues to make efforts to utilize volcanoes into economic potential. Indonesian volcanoes have their own characteristics and beauty. The natural beauty, vegetation formations, diversity of flora and fauna found in the volcanic areas add to their appeal as a tourist attraction. In addition, from the social aspect, the volcanic areas have unique properties, such as myths, cultural history, and even spiritual experiences (Erfurt-Cooper et al., 2015).

On the other hand, mountains and volcanoes have a conservation function that cannot be ignored. Based on this, several volcanoes in Indonesia are designated as conservation areas, with the status of national parks, nature reserves, and nature tourism parks. The effort to designate a conservation area is an initial effort to protect the richness of biodiversity in the designated area. The next task is to manage the conservation area so that it can function as a fortress where various types of natural wealth live, such as flora, fauna, and their ecosystems (Syahadat, 2003).

Tourism management in the conservation areas should be able to balance the economic factors and area preservation. The management of the potential conservation areas for mountains and volcanoes is to open hiking trails. Tourism will have an essential role in the development of a region, this sector can open or increase employment opportunities for people around the region (Utami, 2017). The development of mountain tourism can be a major factor in improving the quality of life of the community as a whole, through sustainable economic development initiatives and environmental preservation. In socio-economic and environmental terms, tourism in mountainous areas is a mixed gift, that, "can be a source of trouble, but also offers many opportunities" (Nepal \& Chipeniuk, 2005).

The development of tourism in the mountains or volcanoes seems to bear fruit in this decade. Climbing is a popular activity among millennials nowadays. Mountaineering is one of the ways this generation spends on holidays, weekends, or even days off from work. Even though it is considered a high-risk activity, it is still increasingly popular (Trauer, 2006). Semeru is the highest mountain on Java Island and the most popular one. Based on the observations and calculations via social media Instagram at the end of December 2019, Semeru Volcano was the most popular volcano. There were 1.280 .083 posts related to the keywords semeru, semerumountain, gunungsemeru, semerumount, mahameru, and mahameru3768mdpl.

This high popularity has an impact on the number of climbers who climb to Semeru Volcano. Its status still active and at Alert Level 2 can cause danger any time. Even so, this can be covered by the climbers' motivation to enjoy the richness and beauty of natural scenery and mountain atmosphere rarely found in urban areas (Setiawan \& Baiquni, 2015). The popularity of Semeru Volcano is an opportunity for the residents around the climbing area to develop the economic activities so that it can increase their welfare. The designation of Semeru Volcano as a conservation area also has an impact on the management and involvement of the residents in the area. The increasing number of climbers can be a great opportunity as well as tough challenges faced by the manager of Semeru Volcano area.

Research to study mountain and mountains as tourist attractions has been widely carried out (Beedie \& Hudson, 2003; Bourdeau et al., 2002; Erfurt-Cooper, 2011; Gulpinar Akbulut, 2014; Heggie, 2010; Sagala et al., 2012; Silva et al., 2013). Other researchers have also conducted social and conservation studies around Bromo Tengger Semeru National Park area, such as: Study of tourism management by TNBTS Center (Utami, 2017); Study of population 
conservation around Semeru Volcano climbing area in Ranupane Village (Atriyantika et al., 2014); and tourist satisfaction with tourist attractions of Semeru Volcano (Setiawan \& Baiquni, 2015).

The research is crucial since Semeru Volcano is a conservation area part of Bromo Tengger Semeru National Park (TnBTS) which needs to be preserved. On the other hand, increasing climbing activity in this area will have an impact on the ecosystem and socio-economic life of the residents around the area. The impact on the local people needs to be observed and studied through a research process.

Moreover, the research findings that examine the economic actors and economic interactions that shape the patterns of economic relations in the volcanic climbing areas have not been carried out. This empty space that this article tries to reveal, especially if the characteristics of the development of the tourism economic in Indonesia are populist-based, it will be interesting to reveal the elements involved, and how these complex relationships are intertwined in a tourism activity process. This is what makes the findings and discussion of this article different from the findings of research examining the tourism in the mountains, mountain, or volcanoes before.

There were four research findings described in this article. First, to describe the results of observations of attractions in the Semeru Volcano conservation area. The second, to identify the economic actors involved in climbing Semeru Volcano. Third, to describe the patterns of the linkage of the economic activities among the actors involved in climbing Semeru Volcano. Fourth, to describe the results of an analysis of the impact of high climbing activity on the ecosystem in the Semeru Volcano conservation area.

\section{RESEARCH METHOD}

The approach in this research was a qualitative exploratory approach. It was conducted for one year, in August 20182019. Its location was not limited to the
Semeru Volcano Area, but also on social media Instagram, especially the accounts related to Semeru Volcano climbing activities, such as the accounts of climbers, savers, and climbing agents. The data collection at the main research location was carried out by the participatory observation in the Semeru Volcano Climbing Area for 5 days 4 nights. Furthermore, it was also observed through social media Instagram. The instruments used were the observation and interview sheets.

The informants in this research were individuals involved in the economic activities in the Semeru Volcano area, such as the climbers, local porters, guides, jeep drivers, and traders. The descriptive analysis was used to reveal the phenomena encountered during the research. Additionally, sociogram was used to determine the patterns of the economic relationships or activities among the business units and individuals in carrying out their roles.

\section{RESULT AND DISCUSSION \\ Description of Attractions in the Semeru Volcano Climbing Conservation Area}

Semeru Volcano climbing area has fascinating attractions. Along the way, climbers will find exotic places. This is what makes climbing Semeru Volcano always memorable for tourists. They give a very good rating for the Semeru Volcano attractions (Setiawan \& Baiquni, 2015). The followings are some of the exotic places encountered when climbing Semeru Volcano.

Ranupane is a lake and name of a village located at an altitude of 2100 masl. It is the starting post for climbing and the entrance gate to the Semeru Volcano climbing area. This post is a place to verify the climbers who have registered online, to check luggage, and to give safety briefings before climbing. This village is productive in agriculture, especially horticulture, but since the climbing in Semeru Volcano is popular, the economic activity of the population has increased in the field of tourism services. The climbers can do camping activities and enjoy 
the beauty of Ranupane and Ranuregolo, two lakes in this region. Several homestays, restaurants, and souvenir shops also exist around the lake and hiking stations. From this post, the climbers travel to Ranukumbolo for around 2-3 hours. Along the way to Ranukumbolo, they will see quite diverse fauna and flora.

Ranukumbolo is a natural lake formed from the joining of water in a large basin. This lake, or "ranu" in the local language, has a heavenly panorama. Surrounded by the hills overgrown with grass, it has its own impression for those who enjoy it. On the edge of the lake, there are old pine trees sacred to the local community. There is also an inscription sacred to the local residents. The activities that climbers can do are setting up a tent, enjoying the beautiful sunrise between the two hills that surround Ranukumbolo, and hunting for photos. There is a prohibition to put limbs into the lake, if violated, there will be social sanctions from the rangers on duty.

The Slope of Love is a slope that the climbers first encounter when continuing the journey from Ranukumbolo. This slope is a mythical attraction fairly popular with the climbers. The content of the myth is "If they think about their loved ones and don't turn back when climbing this slope, then they will love each other." During the observation, it was seen that many climbers believed this myth, they did not want to turn around when passing this Slope of Love.

Oro-oro Ombo is a very wide savanna. After passing the Slope of Love, the climbers can see the expanse of this field. Currently, the vegetation of Oro-oro Ombo is dominated by Verbena brasiliensis Vell, plants originating from South America, belong to Verbenaceae family. A tall, stiff, perennial shrub with narrow leaves, long middle internodes of blue-purple color (Yeo, 2016). The best time to enjoy Oro-oro Ombo is in April-July when Verbena flowers will bloom and spread out wide. The climbers will enjoy incredible views and to continue the journey it is necessary to traverse this meadow. After walking through this meadow, they will arrive at Cemoro
Kandang, the entrance to the vast mountain spruce vegetation (Casuarina junghuhniana).

Vase is a field that is not too broad, found after passing through the mountain spruce vegetation (Casuarina junghuhniana). Located at an altitude of 2600 masl, this field is a place where tourists find edelweiss flowers (Anaphalis longifolia) and senduro (Anaphalis javanica) for the first time along the Semeru Volcano hiking trail. Other vegetations that dominate are, namely: reeds (Imperata cylindrica), fennel (Foeniculum vulgare), Cantigi (Vaccinium varingifolium), and ferns. The climbers usually rest and take self-pictures before continuing their journey to the last post, Kalimati.

Kalimati is a camping area and the last post before heading to the top of Mahameru. This place is a large field of grass interspersed with many edelweiss (Anaphalis longifolia) and senduro (Anaphalis javanica) with the majestic Mahameru peak as the background. It has become a favorite object of photography for tourists. There is a spring called the source of semen by local people. The water is sacred since it is considered holy water and commonly used for religious rituals in Ranupane Village. This post is used to decide to continue climbing to the top. If in the early morning the peak is visible from this post, then the climbers can do a summit attack. Towards Mahameru Peak, it takes an average of six hours from Kalimati.

Mahameru is Semeru Volcano peak. The beautiful scenery from the highest peak on Java Island is the main attraction. The mountains in East Java such as Mount Arjuno, Welirang, Kawi, Argopuro, Lamongan, Penanggungan, Awig-awig, and Bromo in Tengger Caldera can be seen clearly when the weather is clear. Moreover, in the southeast of Mahameru, there is Jonggring Saloko crater which emits the volcanic materials consistently. Therefore, the activity of Semeru Volcano is always declared active since it never stops erupting in an interval of 15 minutes - 20 minutes, so it is in its normal active level (Hakim, 2017). The climbers are only recommended up to Kalimati, but many of them are still trying to get to the top. The time limit at Mahameru 
Peak is only until 10:00 WIB due to the danger of poisonous gases that will blow from the direction of the crater when it is above that hour.

\section{Economic Agents in the Conservation Area}

There are several economic agents involved in Semeru Volcano climbing activities. The agents of this economic activity can be divided into several types. First, the economic agents based on origin are divided into two, external and internal. The external economic agents are the people or business units who do not come from Bromo Tengger Semeru National Park area and are involved in Semeru Volcano climbing activities. Meanwhile, the internal economic agents are the local people or business units (local residents) who homebase in Bromo Tengger Semeru National Park and are involved in facilitating when climbing Semeru Volcano. Table 2 shows the external and internal economic agents who carry out the economic activities in the Mount Semeru climbing area.

Table 1. Types of Economic Agents in the Semeru Volcano Climbing Area

\begin{tabular}{ll}
\hline \multicolumn{1}{c}{ External } & \multicolumn{1}{c}{ Internal } \\
\hline Climber, Open & Local Guide \\
Trip Service, & (Saver), Trader, \\
Basecamp Owner, & Local Porter, \\
Jeep Driver, & Homestay Owner \\
External Porter, & \\
External Guide & \\
\hline
\end{tabular}

Source: Research Findings, 2018-2019

Climbers are the economic agents who have a huge impact on the economic activity in the Semeru Volcano climbing area and become the target market. They can also be said to be consumers in the Semeru Volcano climbing activity. The TNBTS Conservation Center has a special scheme for the climbers who will climb to Semeru Volcano.

The quota of climbers allowed to climb is limited to only 600 people/day. It is implemented to maintain the carrying capacity and conservation function of the national park. The climbers are required to make online bookings to get the quota and also obtain a Conservation Area Entry Permit (Simaksi). Online booking is enforced to avoid the accumulation of climbers on the waiting list at Ranupane climbing gate. Before online booking was enforced, many climbers often delayed climbing for 1-3 days due to limited climbing quotas. This system actually makes climbers have the certainty to start climbing.

The fee that should be paid to enter the Semeru Volcano conservation area for domestic tourists is Rp. 29.000 per day and Rp. 34.000 for holidays. Meanwhile, for foreign tourists, it is Rp. 220.000 per day and Rp. 320.000 for holidays. The ideal climbing that many climbers do is around 4 days 3 nights. This fee includes insurance valid until Kalimati Post. Meanwhile, climbing up to Mahameru Peak does not get insurance guarantees and is actually not recommended since Semeru Volcano is on standby status throughout the year, and every 30-45 minutes it releases volcanic ash from Jonggring Saloko Crater.

Types of climbers who visit and climb Semeru Volcano can be divided into several types. First, solo climber is a climber who climbs alone, not part of a climbing group. During the climbing, he/she is asked to join other groups by volunteers. Second, large group climbers are climbers who climb in groups, consisting of 6-15 people. Usually they are friends from the same institution, community, or nature lover activity. Next, small group climbers are a group of climbers consisting of 2-5 people. They usually hire local guides and porters to help them when climbing.

The economic agents fairly striking in climbing Semeru Volcano recently are Open Trip Services. They are a new phenomenon in the world of mountaineering in Indonesia. They are people/business units that provide facilities to climbers to make it easier to climb a mountain for a certain fee. They use social media a lot (especially Instagram) to market their open trip packages to Semeru Volcano. 
The open trip participants managed in one climb range from 20-50 participants. Based on searches through Instagram, they are mostly managed by the business agents from outside the region, such as Jakarta, Semarang, Yogyakarta, Malang, Bandar Lampung, and Bandung.

These open trip services actually do not only provide climbing services for Semeru Volcano, but this mountain is one of the most opened climbing destinations. The open trip services really facilitate climbers who want to climb comfortably. They provide facilities such as transportation from the meeting point (mepo) to the climbing basecamp, transportation to the climbing post (jeep), registration/simaksi, medical documents, camping equipment, food during the climbing, guides, external porters, and documentation. In contrast, climbers' personal supplies and equipment are the responsibility of each participant. Open trip climbers consist of various groups ranging from domestic and foreign tourists. Foreign climbers encountered following these services came from Malaysia and Thailand.

"Looking for Climbing Partner" is a fairly new and unique phenomenon that has recently occurred. It means people who offer to share the cost of climbing. They use social media to find other climbers who want to climb to Semeru Volcano but do not have enough members or personnel. The highest sharing cost is actually to rent a Jeep from Tumpang to Ranupane, with more groups, this cost will be increasingly reduced. The climbers who do it meet at an agreed meeting point. The sensation they get is new friends from different regions who have the same pleasure.

The internal economic agents who have a dual role are local guides. They call themselves volunteer or saver. Their economic role is as a guide for climbers to climb Semeru Volcano. Meanwhile, their other role is as environmental savior/volunteer for the Semeru Volcano conservation area. As economic agents, they open scouting services to get to Mahameru Peak. The climbers who use the services of local guides are often foreign tourists. They have fairly good English skills and are very familiar with the climbing terrain, natural formations, cultural history, and flora and fauna along the hiking trail, so they are able to provide fairly good explanations for each tourist attraction. The second role is as a conservation volunteer. Some of their roles are namely: 1) Leading the initial briefing before climbing; 2) Checking the luggage of climbers allowed to enter the conservation area; 3) Keeping the environment clean in the area; 4) Ensuring climbers' trash is brought down; 5) Carrying out rescue and evacuation when there are climbers who need help; 6) Ensuring safety on the hiking trail.

The local porters are the economic actors fairly common along the hiking trail. They are needed by large or medium climbing groups. There are two types of services provided, namely drop off and full service. Drop off service is delivering goods at a certain predetermined point while full service is a service to transport climber goods according to the climbing time, what local porters do for full service is carrying logistics/goods, cooking, and fetching water. The fee for full service is Rp. 250.000 per day with an estimate of the goods carried by one porter for two climbers. The local porters usually choose the fastest route different from the climbers.

\section{Patterns of Economic Activities in Conservation Area}

The popularity of climbing Semeru Volcano has an impact on changes in the patterns of economic activities of the surrounding population. The majority of the population around the climbing area, especially Ranupane, makes their living in agriculture (Atriyantika et al., 2014). Each economic agent involved in the Semeru Volcano climbing area will be linked to other economic agents. The economic agents from internal region and external region have a relationship that has a positive impact from a business perspective. This relationship pattern can be seen in Figure 1 . 
The economic agents who have the most positive relationship with other economic agents in the climbing area are climbers. They are the main consumers in the economic activities of climbing Semeru Volcano. They can have a positive impact on the internal regional agents such as homestay owners, traders, local guides, and local porters. On top of that, the positive interaction occurs between climbers and external economic agents, such as jeep drivers, base camp owners, and open trip services. Meanwhile, external porters or external guides do not make direct contact, but usually through open trip services.

Open trip services have a fairly wide range of interactions in the climbing activities. The climbing planning of several large open trips is made to involve local personnel to contribute to the region's internal economic agents, such as local porters, and local traders. Local porters are used by open trip services to drop off logistics and camping equipment, while traders are asked to prepare logistics or supplies when they feel they are lacking. The open trip services also accommodate external porters who get the task of carrying climber equipment who do not want to bother carrying personal equipment, while external guides are asked to guide and look after climbers who use open trip services.

Jeep owners or drivers have a unique pattern of collaborative interactions. The majority of them are external agents, who live around Tumpang area, Malang. In addition to taking the climbers to Semeru Volcano Climbing Post, they actually also serve tours to Bromo Volcano which starts early in the morning. The collaboration carried out by Jeep drivers is to collaborate with basecamp owners, local guides (savers), and open trip services. Especially with open trips, cooperation is carried out to pick up and drop off at a predetermined time.

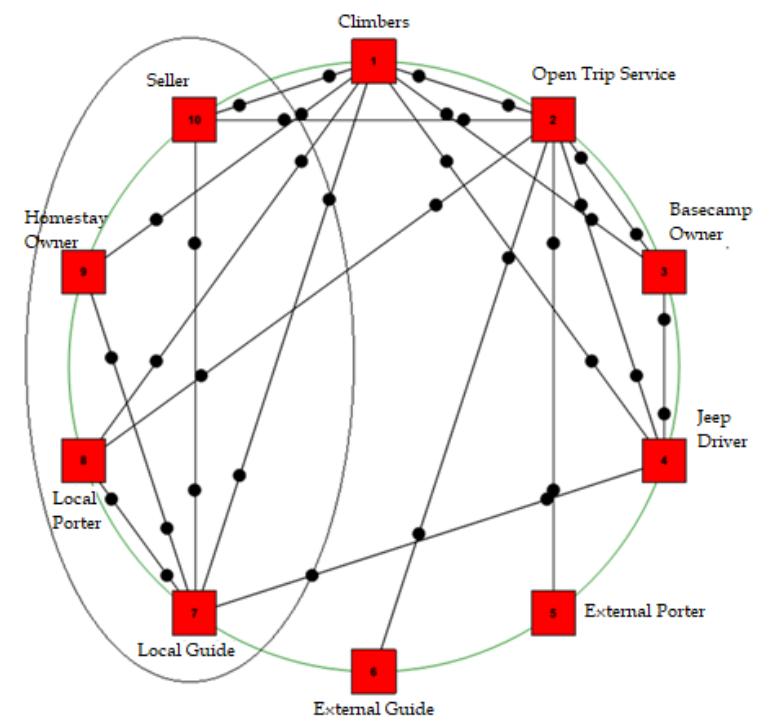

Description:

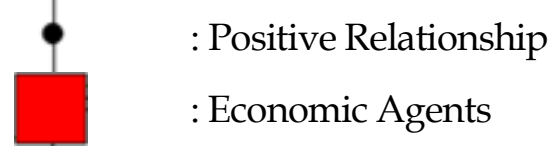

Figure 1. Sociogram of Relationship Patterns of Economic Agents in Semeru Volcano Conservation Area

Source: Research Findings, 2018-2019 
Based on Sociogram of Figure 1, it can be concluded that the patterns of economic activities between the internal and external agents is positively connected. The climbers as consumers have a big role in the development of mount tourism on Semeru Volcano. Likewise, open trip services have an extensive network to accommodate climbers for climbing, if this pattern is maintained, there will be positive sustainability between the external and internal economic agents in the Semeru Volcano climbing area.

There is something fairly interesting from the research findings that there was no economic linkage between the open trip services and local guides. This actually happens since a competition is formed in serving climbing. Local guides, who also act as savers or volunteers, have business activities to accompany climbers to enter the area. Of the several local guides encountered during the research process, most of those who used the services of local guides were the foreign climbers. Local guides are also leaders for preparing the accommodation, routes, jeeps, and porters for climbing. Usually, they have the ability to explain natural, cultural/mythical, and social phenomena encountered during climbing. Meanwhile, the role of open trip services is limited to preparing accommodation, routes, and porters for the climbing activities only. The external guide also only have a role as a guide to accompany the climbers.

Jeep rental is an economic agent from outside the area since its base is in Tumpang area, 2 hours away from Ranupane Climbing Post. It usually works together with the base camp owners in Tumpang area as well. Meanwhile, homestays in the area do not have a positive relationship pattern since they only serve climbers who spend the night around Ranupane Climbing Post.

The patterns of economic relations that exists between the internal and external agents occurs harmoniously, even though there is competition not very visible and disturbing the climbing activities. The internal economic agents respond to all external agents as guests, who need to be served and continue to comply with the climbing safety procedures in the Semeru Volcano Area so that the synergy between the external and internal economic agents remains sustainable.

\section{Impacts on Conservation Area}

Semeru Volcano, which is very popular, has an impact on massive climbing activities. This absolutely has an impact on areas included in the conservation zone. Through the observations and tracing carried out in the climbing area and following developments in the cyberspace, there are two problems faced by the Semeru Volcano conservation area as a result of this fairly massive economic activities. Those two problems are garbage and erosion.

Garbage seems to be a problem faced by the managers and volunteers in the Semeru Volcano climbing area in recent years. The garbage often found is of plastic type, the product of the irresponsible climbers and not monitored by the volunteers or rangers. The plastics commonly found along the hiking trail are candy wrappers, chocolate, honey, instant noodles, and bottled water. Some of them is scattered along the hiking trail, but what is surprising is when a large amount of trash is found hidden in the bush. This kind of behavior is very threatening to the environmental sustainability in the Semeru Volcano climbing area.

Another waste fairly disturbing to the aesthetics and environmental ethics is the large amount of wet tissue waste. This garbage is produced from climbing which involves defecating carelessly. The smell of urine and piles of wet wipes can be seen around Ranukumbolo, Kalimati, Cemoro Kandang, and Oro-oro Ombo. Even though currently the managers have prepared a wet bathroom for the climber toilets and prohibit the use of wet wipes in the conservation area in 
Ranukumbolo, there are still climbers irresponsible for doing this.

Erosion is the second problem. It is a natural process, but it can be accelerated if human activities are affected. The climbing carried out still can accelerate the process of erosion in the Semeru Volcano conservation area. Overall, TNBTS is dominated by moderate erosion (60-180 tons/ha/year) covering an area of 43.694 ha $(86.9 \%)$ (Harjadi, 2008). Even though the data are entirely from the entire national park area, it is still necessary to be aware of and provide education for tourists who climb since if left unchecked it will endanger the ecosystem in the climbing area.

The furrow and trench erosion is seen at several points of the hiking trail. One of them is around Ranukumbolo. In the last ten years, the path used to reach the top of the Slope of Love has become several paths, this is the evidence of soil erosion caused by the opening of the path by climbers. The exploration of climbers around Ranukumbolo also produces open paths that accelerate erosion since it opens the grass that covers the ground. It can be ascertained that furrow erosion and some trench erosion occur around Ranukumbolo. It is feared that the erosion process that occurs around Ranukumbolo will become a sedimentation process and have an impact on the silting of Ranukumbolo.

The concept of tourism management in its implementation should meet three sustainability elements, namely: (1) ecological aspect, (2) social aspect, and (3) economic aspect (Umar, 2018). Hence, these three elements should be the focus of the management of the Semeru Volcano climbing area. On the ecological aspect, actually the managers, residents, and volunteers are working very hard in maintaining the sustainability of the Semeru Volcano conservation area. This is one of the distinctive characteristics of the management of the Semeru Volcano climbing area which actively involves local communities to preserve nature and economic activities, and maintain socio- cultural values throughout the climbing area, or known as CBT - Community Based Tourism concept (Sugiharto et al., 2018).

The activity of climbing Semeru Volcano is often closed temporarily for the reason of restoring the ecosystem. Usually, the ecosystem restoration is carried out at the beginning of the year (January) to mid-year (April), or what is commonly referred to as the climbing season. The closure is also carried out when there are extraordinary natural processes in the conservation area, such as landslides, forest fires, and bad weather. During the closing period, a joint team of volunteers (savers), local residents, and TNBTS center carries out an ecosystem restoration operation by carrying out garbage transportation, repairing pathways, and strengthening climbing facilities and infrastructure.

The tourism in Semeru Volcano should have a clear type of tourism. The existing forest, savanna, and lake conservation areas need to be more closely guarded in order to remain sustainable. The tourism in the mountains should use the concept of ecotourism, which does not damage the natural and cultural environment, provides economic, environmental, and social benefits for local residents, and offers a high-quality experience (passive: walking, hiking and learning about the environment) for visitors (Dowling, 2014; Erfurt-Cooper et al., 2015; Gulpınar Akbulut, 2014; Nepal, 2002).

\section{CONCLUSIONS}

The climbing activity on Semeru Volcano has an impact on the social and economic life of the population. The local residents around the area definitely feel the impact, but this research finds that there are economic and business agents who come from outside the area. They have a very big opportunity to do a climbing tourism business or what is called an open trip. Based on the research findings, the economic agents can be classified based on the location of their business, namely the so-called 
internal and external economic agents. The patterns of relations or interactions and economic transactions among the economic actors are interrelated and very positive in nature. Although there is a potential that allows for competition and conflict between the open trip services and local guides, this does not happen due to the wisdom possessed by the internal economic agents, especially the local guides mostly the indigenous Tengger Tribe. The research findings also reveal that there are two impacts from this high climbing activity. The erosion caused by the camping activities and widening of the hiking trail, as well as the garbage from the climbers, are serious problems, even though the area managers have sufficiently emphasized this garbage procedures to the climbers.

Although the managers, volunteers (savers), and other local residents have tried to protect it, the problems still occur. Some of the proposals put forward are related to the results of this research, namely, first, by clearly defining and disseminating the types of tourism in Semeru Volcano, which can be in the form of ecotourism, geotourism, or adventure tourism, so the management and regulation of economic actors' contributions are clear. Second, the problems of erosion and garbage are none other than the results of the climbers' activity, so for supervision it is better to involve the local guides and local porters who have been included in a climbing tour package that can be included in the entrance ticket. Third, education for tourists who climb in the area should be improved.

\section{ACKNOWLEDGEMENTS}

The authors would like to thank the parties involved in this research, especially TNBTS managers, volunteers, and porters who assisted in the data collection.

\section{REFERENCES}

Atriyantika, M., Arief, H., \& Sunarminto, T. (2014). Studi Konservasi Sumberdaya
Alam Hayati Pada Masyarakat Tengger Di Resort Ranu Pani, Taman Nasional Bromo Tengger Semeru. Media Konservasi, 19(1), 1-11. https://doi.org/10.29244/medkon.19. 1.

Beedie, P., \& Hudson, S. (2003). Emergence of mountain-based adventure tourism. Annals of Tourism Research, 30(3), 625643. https://doi.org/10.1016/S01607383(03)00043-4

Bourdeau, P., Corneloup, J., \& Mao, P. (2002). Adventure sports and tourism in the French mountains: Dynamics of change and challenges for sustainable development. Current Issues in Tourism, 5(1), 22-32. https://doi.org/10.1080/136835002086 67905

Dowling, R. K. (2014). Global Geotourism An Emerging Form of Sustainable Tourism. Czech Journal of Tourism, 2(2), 59-79. https://doi.org/10.2478/cjot2013-0004

Erfurt-Cooper, P. (2011). Geotourism in volcanic and geothermal environments: Playing with fire? Geoheritage, 3(3), 187193. https://doi.org/10.1007/s12371010-0025-6

Erfurt-Cooper, P., Sigurdsson, H., \& Lopes, R. M. C. (2015). Volcanoes and Tourism. In The Encyclopedia of Volcanoes (Second Edi). Elsevier Inc. https://doi.org/10.1016/b978-0-12385938-9.00075-4

Gulpınar Akbulut. (2014). Volcano Tourism in Turkey. In Volcanic Tourist Destinations, Geoheritage, Geoparks and Geotourism (pp. 89-102). https:/ / doi.org/10.1007/978-3-64216191-9

Hakim, A. R. (2017). Analisis Energi Gempa Letusan Gunung Semeru 09 Oktober 2009. Jurnal Pendidikan MIPA, 7(1), 3035.

Harjadi, B. (2008). Perhitungan Tingkat Erosi Kualitatif Di Taman Nasional Bromo Tengger Semeru. Seminar Nasional Geomatika 2017: Inovasi Teknologi Penyediaan Informasi Eospasial Untuk Pembangunan Berkelanjutan Erosi, 291- 
298.

Heggie, T. W. (2010). Geotourism and public safety in volcanic environments. In Volcano and Geothermal Tourism: Sustainable Geo-Resources for Leisure and Recreation.

https://doi.org/10.4324/978184977518 2

Nepal, S. K. (2002). Mountain Ecotourism and Sustainable Development. Mountain Research and Development, 22(2), 104-109. https:// doi.org/10.1659/02764741(2002)022[0104:measd]2.0.co;2

Nepal, S. K., \& Chipeniuk, R. (2005). Mountain tourism: Toward a conceptual framework. Tourism Geographies, 7(3), 313-333. https://doi.org/10.1080/146166805001 64849

Sagala, S., Rosyidie, A., Pratama, A., Wimbardana, R., \& Wijayanti, A. (2012). Promoting Volcano Tourism in Hazard Zone Area for Rebuilding Local Economy: Case study of Tourism in Cangkringan Sub-District, Mt. Merapi, Yogyakarta. International Conference on Sustainable Built Environment, Yogyakarta., 1-13. http://www.pl.itb.ac.id/dosen/sas/w p-content/uploads/2015/07/Sagala-

Promoting-Volcano-Tourism-inHazard-Zone-Area-for-RebuildingLocal-Economy.pdf

Setiawan, Y. N., \& Baiquni, M. (2015). Penilaian Wisatawan Terhadap Kualitas Obyek Wisata Gunungapi Semeru. JBI, 4(1), 178-187.

SI-USGS. (2009). Global Volcanism Program. Http://Www.Volcano.Si.Edu/Reports /Usgs/.

http://www.volcano.si.edu/reports/ usgs/

Silva, C., Kastenholz, E., \& Abrantes, J. L. (2013). Place-attachment, destination image and impacts of tourism in mountain destinations. An International Journal of Tourism and Hospitality Research, 24(1), 17-29. https://doi.org/10.1080/13032917.201 2.762312
Sugiharto, S., Delita, F., \& Sidauruk, T. (2018). Tingkat Kesiapan Masyarakat Lokal Terhadap Pengembangan Community Based Tourism (CBT) di Kabupaten Samosir. Jurnal Geografi, 10(2),

157. https://doi.org/10.24114/jg.v10i2.104 19

Syahadat, E. (2003). The Factors Witch Are Influences To A Tourism Visitor In Gede Pangrango National Park (Gpnp). Jurnal Penelitian Sosial Dan Ekonomi Kehutanan, 3(1), 1-14.

Trauer, B. (2006). Conceptualizing special interest tourism - frameworks for analysis. Tourism Management, 27(2006), 183-200.

https://doi.org/10.1016/j.tourman.20 04.10 .004

Umar, M. . (2018). Potensi Ekowisata Bahari Pada Pulau-Pulau Kecil Di Halmahera Selatan. Jurnal Geografi, 10(2), 117-128.

Utami, H. S. (2017). Pengelolaan Kawasan Pariwisata (Studi di Balai Besar Taman Nasional Bromo Tengger Semeru) Hadi. Jurnal Ilmiah Administrasi Publik( JIAP ), 3(1), 13-20.

Yeo, P. F. (2016). A Re-Definition of Verbena brasiliensis. Springer on Behalf of Royal Botanic Gardens, Kew, 45(1), 101-120. 